УДК 811.14’02

DOI https://doi.org/10.26661/2414-9594-2020-2-15

\title{
СЛОВОТВІР ПРИКМЕТНИКА (НА МАТЕРІАЛІ ДАВНЬОГРЕЦЬКОЇ МОВИ)
}

\author{
Куйбіда X. I. \\ кандидат філологічних наук, \\ доиент кафедри класичної філології \\ Львівський національний університет імені Івана Франка \\ вул. Університетська, 1, Львів, Україна \\ orcid.org/0000-0002-7637-9606 \\ khristina2209@gmail.com
}

\begin{abstract}
Ключові слова: ад'єктив, деривація, композит, юкстапозит, мотивація, спосіб словотворення, дериваційні можливості.
\end{abstract}

У статті висвітлено основні словотвірні особливості похідних прикметників давньогрецької мови. Спершу в роботі окреслено відмінності між первісними та похідними одиницями. Похідні ад'єктиви розглянуто з погляду словотвірної структури та словотвірної мотивації. Наведено теоретичну класифікацію способів словотворення, яка найбільше відповідає специфіці давньогрецької мови. Окремо виділено групу похідних слів, утворених за допомогою однієї основи, та групу слів, які утворюються на базі двох основ. Проаналізовано детальніше суфіксацію та префіксацію як основні способи афіксального словотворення. Виділено найбільш характерні для давньогрецького ад'єктива словотвірні форманти (суфікси, префікси, інтерфікси). Серед способів складання найпродуктивнішим є основоскладання. Ад’ єктивні композити розглянуто відповідно до їхніх структурних елементів, моделей утворення, словотвірного значення. Щодо типу відношення між компонентами композитів, виділено адитивний і детермінативний типи зв'язку. Окрему увагу присвячено екзоцентричним за семантичними ознаками детермінативним складним прикметникам типу багувриги, наявність яких вважається невід'ємною особливістю давньогрецької мови. Словоскладання, як зазначено, не $є$ характерним для системи давньогрецького прикметника способом словотворення. Юкстапозитиад'єктиви утворилися здебільшого на базі словосполучень із першим адвербіальним компонентом. Звернено увагу також на особливості внутрішньої мотивації складних слів, виділено спільні та відмінні риси словосполучення та композита. Окремим аспектом аналізу словотвірних особливостей грецьких ад'єктивів у представленій праці є 3'ясування дериваційних можливостей аналізованих похідних як ціліснооформлених одиниць, що стосується їх активності в утворенні вторинних дериватів. Словотвірні потенції давньогрецьких похідних прикметників як твірних баз у подальших процесах деривації продемонстровано на основі понять словотвірної пари та словотвірної парадигми, що становлять безпосередній зв’язок між дериватами та твірними лексичними одиницями. 


\title{
THE WORD-FORMATION OF AN ADJECTIVE (ON THE MATERIAL OF ANCIENT GREEK)
}

\author{
Kuibida Kh. I. \\ Candidate of Philological Sciences, \\ Associate Professor at the Department of Classical Philology \\ Ivan Franko Lviv National University \\ Universytetska str., 1, Lviv, Ukraine \\ orcid.org/0000-0002-7637-9606 \\ khristina2209@gmail.com
}

Key words: adjective, derivation, compound, juxtaposite, motivation, way of word-formation, derivational potentials.

\begin{abstract}
The article reveals the main word-forming features of the derivative adjectives in Ancient Greek. First of all the main differences between the primitive and the derived adjectives are emphasized in the paper. The derived words are considered in terms of word-forming structure and word-forming motivation. The theoretical classification of word-forming methods, that mostly corresponds to the specifics of the Ancient Greek, is given in the work. A group of derivatives formed on the base of one stem and a group of words formed on the base of two stems are singled out. Suffixation and prefixation as the main ways of affix word-formation are analyzed in details. The most typical of Ancient Greek adjective formants (suffixes, prefixes, interfixes) are listed in the paper. Composition, as noted, is the most productive way of word-formation. The compound adjectives are studied according to their structural elements, word-forming models and meaning. The relations between the compositional elements of compounds are divided into two types: additive and determinative. A particular attention is paid to the exocentric, due to its semantic peculiarities, determinative compound adjectives of the type bahuvrihi, that are considered to be a special feature of the Ancient Greek. The composition of words, as noted, is a rare way of word formation in the system of the Ancient Greek adjective. Juxtaposites were formed mostly on the basis of word phrases with the adverb in the first part of the compound. A special attention is paid to the paculiarities of the internal motivation of compounds. The common and distinctive features between the word phrases and compounds are revealed. Another aspect of the analysis of word-forming features of Greek adjectives in the presented work is to clarify the derivational potentials of the analyzed derivatives as integral units, that concerns their activity in the process of the secondary derivation. The word-forming potentials of the Greek derivative adjectives as creational bases in the processes of the further derivation are presented through the concepts of the word-forming pair and paradigm. They are considered to be a direct connection between the derivatives and the forming lexical units.
\end{abstract}

Розвиток словотвірних процесів, а також процеси становлення прикметника як частини мови сягають ще періоду античності, велике ж розмаїття ад'єктивів (особливо складних) вважається винятковою та невід'ємною особливістю грецької мови. На сучасному етапі розвитку лінгвістичної науки особливе зацікавлення у мовознавців викликають прикметники з ускладненою структурою, утворені внаслідок процесів словотворення (як одного 3 найпоширеніших і найпродуктивніших способів поповнення й оновлення лексичного складу мови $[9$, с. 56]).
Важливе значення похідних слів, особливо складних, підкреслювали ще античні вчені. Наприклад, Аристотель зазначав: «У складних іменах все не так, як у простих, бо у простих жодна частина не має значення, а у складних словах кожна частина має певний смисл» [1, с.94].

На основі класичних мов прикметники досліджували: латинської - К. Култер, М. Льойман, Р. Л. Оліщук, Дж. Пултні та ін.; давньогрецької мови - А. Бланк, Е. Гемп, Г. Генінгсвальд, Р. Говтрі, Л. Л. Звонська, М. Й. Петришин, I. Манолессу, Т. Мейсснер, А. Раллі, Дж. Річардс, 
О. Трібюлато, Е. Швіцер. Учені аналізують морфемну будову, структурні типи та семантичні різновиди ад'єктивів, розкриваючи лише окремі аспекти проблематики.

Актуальність статті полягає у зростанні інтересу до процесу творення слів у сучасній лінгвістиці, відсутності окремого дослідження, присвяченого способам творення прикметників у давньогрецькій мові (далі - ДГ). Спроба ж систематизувати словотвірні особливості ДГ похідних ад'єктивів на основі аналізу способів їх творення, відповідно до структури, семантики, внутрішньої мотивації, та продуктивності в подальших процесах деривації складає наукову новизну роботи.

Метою представленого дослідження є визначення основних словотвірних особливостей прикметника на прикладі ДГ. Для досягнення окресленої мети необхідним стало вирішення таких завдань: дати визначення використаних у роботі понять і термінів, проаналізувати основні способи творення давньогрецьких похідних прикметників, виділити їхні словотвірні елементи, розглянути структурну та семантичну мотивацію.

Об'єктом дослідження є давньогрецькі похідні прикметники, їх мотиваційна база та словотвірні форманти. Предметом аналізу є систематизація способів творення ДГ похідних ад'єктивів на основі їхьої структури, семантичної мотивації, дериваційних особливостей.

Похідні слова $\epsilon$ предметом вивчення словотвору, i тому огляд прикметників у цьому аспекті полягає у з'ясуванні їхньої словотвірної структури та семантичної мотивації (слід зазначити, що у широкому розумінні мотивація - це і $\epsilon$ похідність). У словотворі традиційно усталеними є поняття: структурна похідність, семантична похідність або мотивація [7; 12].

Словотвірна похідність (мотивація) - формально-семантичні відношення між членами словотвірної пари, один компонент із яких - твірне слово (твірна база, мотиваційна база), а інший похідне слово (дериват, мотивоване слово). Отже, про словотвірні особливості прикметника можна говорити тільки на матеріалі похідних ад'єктивів, адже первісні слова не мають ні структурносемантичної мотивації, ні словотвірного значення.

Питання про відмінність між похідними та первісними словами $є$ ключовим питанням синхронного словотвірного аналізу, оскільки не завжди слова, які в морфемному складі мають афікси, $є$ дериваційно-мотивованими у синхронії (ßıот́боо - життєвий). Серед трьох семантичних розрядів обов'язковою похідністю характе-

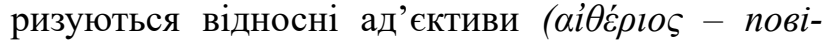
тряний) і присвійні (їлльоৎ - кінський). Більша частина якісних прикметників - це слова 3 немотивованою семантикою, які передають безвідносну ознаку і мають кореневу основу, тобто $є$ первіс-

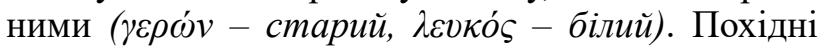
якісні прикметники у морфемній структурі містять прозорі словотворчі суфікси, а матеріальною базою їх творення є іменникові й дієслівні основи [3, с. 144]. Вони виражають словотвірну семан-

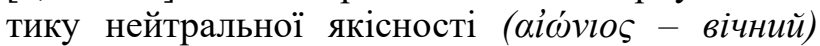
або виразну спеціалізовану якісність, наприклад, інтенсивність вияву, подібність, схильність до

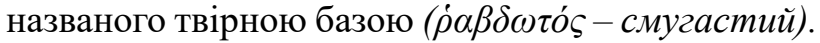

Похідні ад'єктиви, як і інші лексичні одиниці, утворюються 3 наявних у мові словотворчих ресурсів (твірних баз і словотворчих засобів). У процесі деривації ці ресурси використовуються неоднаково, саме в цьому й виявляються різні способи словотворення. «Способи словотворення - це комплексна система використання різних структурних словотворчих засобів і способів утворення дериватем із їхніми словотвірними структурами - словотвірними формами та словотвірним значенням на всіх етапах розвитку мови» [12, с. 26]. Отже, це шлях, прийом творення нового слова на основі твірної (мотиваційної) бази з допомогою словотворчих засобів (формантів, афіксів).

Словотвірні процеси у грецькій мові зазвичай поділяють [20] на - деривацію та складання (у вітчизняній лінгвістиці знаходимо поняття афіксації та складання [11], або ж творення слів 3 однією основою та кількома [10]). Схарактеризуємо, отже, найбільш характерні для давньогрецького ад'єктива способи словотворення.

На сучасному етапі грецька морфологія переважно базується на понятті основи, адже більшість слів утворюється шляхом додавання афікса - префікса або суфікса - до основи (деривація / афіксація), або основи до іншої основи чи слова (складання). Основи ж можуть бути морфологічно простими та морфологічно складними. За синхронічними ознаками морфологічно прості основи збігаються 3 коренем. У давньогрецькій (класичній) грецькій (V-IV ст. до н. е.), однак існувала різниця між поняттями основи та кореня (в системі іменника та дієслова), оскільки основу слова в деяких випадках становив корінь у сукупності з тематичним голосним (на сучасному етапі тематичні голосні вважаються здебільшого частинами флексій [19]). У статті послуговуємося терміном «основа» для позначення як основ, так і коренів. На флексіях, які є невід'ємною частиною грецького прикметника, не акцентуємо уваги (називаючи кінцевий формант суфіксом). Під твірною основою розуміємо основу, від якої утворюється нове слово певним способом словотворення, частину слова, що співвідносить похідне слово із твірною базою і разом з афіксом формує його словотвірну структуру. 
Отже, розглядатимемо ад'єктиви таких способів творення - 3 однією твірною основою (похідні прості) та 3 двома і більше твірними основами (похідні складні).

Прості ад'єктиви складаються $з$ однієї основи (що $\epsilon$ носієм основного лексичного значення слова), дериваційного суфікса та / або префікса. Корінь та афікс можуть утворювати основу для подальших процесів деривації (на підставі цього, розрізняють прості та складні основи). До одиниць, утворених афіксальним способом, належать суфіксальні та префіксальні деривати.

Найбільш типовим для прикметника способом деривації є суфіксація. Суфікси в ДГ практично всі $є$ автентичні, за винятком нечисленних догрецьких запозичень, які є нечіткими, непродуктивними й не виділяються окремо [17, с. 2044]. Способом суфіксації у ДГ утворюються похідні ад'єктиви від інших частин мови, а саме від: дієслів, іменників, прислівників [15]. Від прикметників утворюються деривати 3 дещо зміненим лексичним значенням.

Найважливішими віддієслівними суфіксами

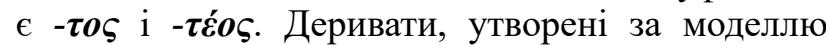
$\mathrm{V}+\boldsymbol{- \tau o \varsigma / ~ - \tau \varepsilon ́ o \varsigma , ~ н а з и в а ю т ь с я ~ р \eta \mu \alpha \tau ı к ́ ́ ~ \varepsilon л і ́ \theta \varepsilon \tau \alpha / ~}$ adiectiva verbalia. Наприклад, прикметники, утво-

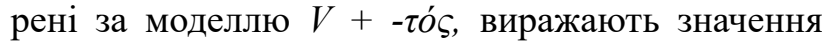
«результат дії»: үра́ саний). Лексеми, утворені за моделлю $V+$

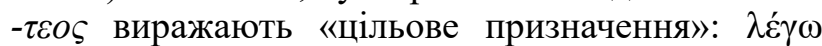

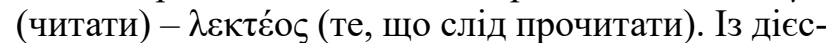
лівною основою сполучаються також суфікси - $а \varsigma /$

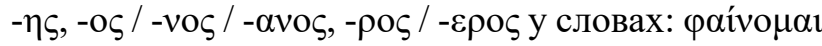

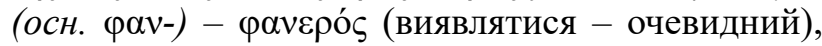
$\psi \varepsilon v ́ \delta о \mu \alpha \imath-\psi \varepsilon v \delta \dot{\zeta}$ - (обманювати - оманливий), $\pi \varepsilon i \theta \omega(\pi \varepsilon \imath \theta-, \pi \imath \theta-)-\pi \imath \theta \alpha \nu$ ó $\varsigma$ (переконувати - переконливий, вірогідний). За допомогою суфіксів $-\imath \kappa o \varsigma,-\tau \imath \kappa o \varsigma,-\imath \mu о \varsigma,-\mu \omega v,-\tau \eta \rho \imath о \varsigma$ утворюються прикметники, які виражають ознаку можливості, схильності чи наміру здійснити позначену дієсло-

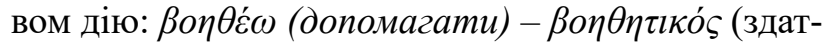

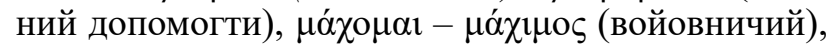

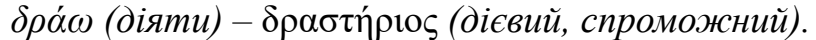

Найважливішим суфіксом у відіменниковій деривації прикметників $\epsilon$-los, який відповідно до особливостей основи (кінцевого голосного та семантики) представлений аломорфами

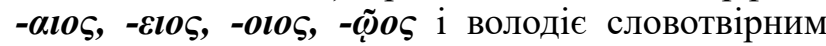
значенням «належність чомусь / комусь, походження»: $\tau \dot{\chi \chi \eta ~(в и п а д о к) ~-~ \tau v \chi \alpha і ̃ ~(в и п а д к о в и и ̆) ~}$

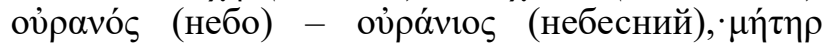
(мати) - $-\mu \eta \tau \rho \tilde{\omega} о \varsigma$ (материнський), $\alpha \alpha v \theta \rho \omega \pi о \varsigma$

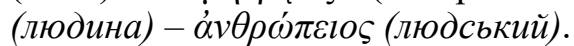

Суфікс -ко́

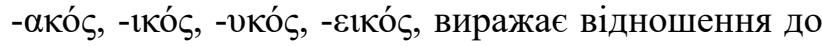
чогось / когось чи можливість / здатність щось

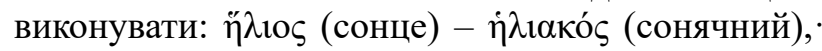

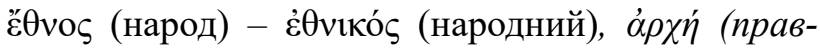

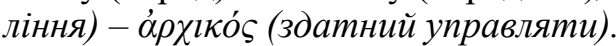

За допомогою обох суфіксів (-los,-ко́ ऽ) утворюються посесивні прикметники від власних назв, інколи функціонуючи паралельно: Kó $\boldsymbol{\rho} \boldsymbol{\imath} \boldsymbol{\theta o s}$

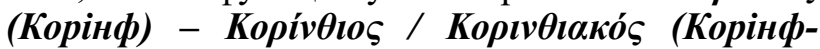
ський).

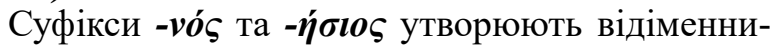
кові ад'єктиви на позначення часу та місця: е̌то

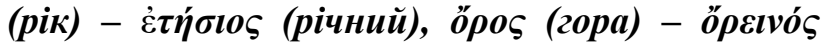

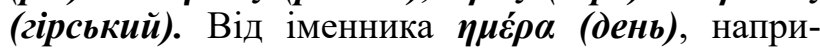
клад, за допомогою трьох згаданих вище суфіксів утворюються паралельні форми 3 різним відтінком значення: $\dot{\eta} \boldsymbol{\mu} \varepsilon \rho \dot{\eta} \sigma ı \varsigma$ / $\dot{\eta} \boldsymbol{\mu} \varepsilon \dot{\rho}$ короткий), $\dot{\eta} \mu \varepsilon \rho \imath{ }^{\prime} \varsigma$ (денний).

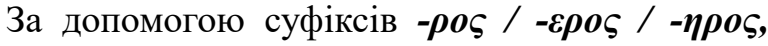
- $\alpha \lambda \varepsilon о \varsigma$ утворюються ад'єктиви, які виражають характеристику за зовнішніми / внутрішніми,

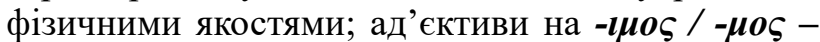

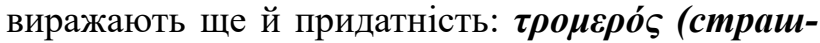

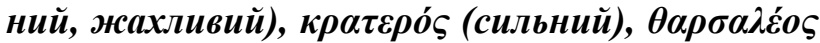

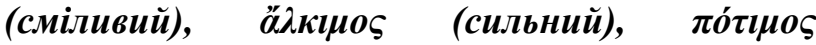
(питтевий).

Від основи іменника утворюються також ад'єктиви 3 допомогою суфіксів - $\boldsymbol{\varepsilon} \boldsymbol{l}$ (позначають напов-

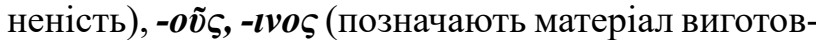

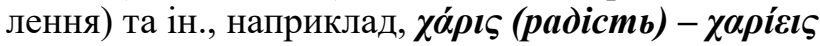

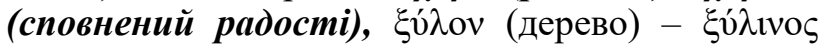

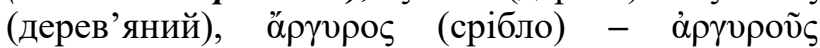
(срібний).

Відадвербіальні прикметники характеризу-

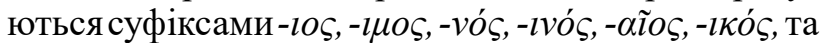
виражають ознаку стосовно місця та часу: ö $л \sigma \theta \varepsilon v$

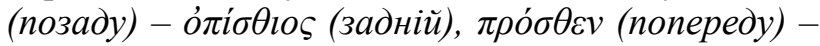

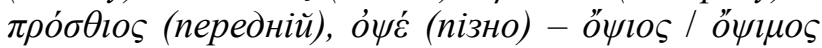

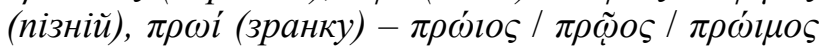

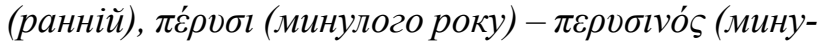
лорічний), $\chi \theta \dot{\varepsilon} \varsigma$ (вчора) - $\chi \varepsilon \varepsilon \sigma \imath$ о́ (вчорашній), $\dot{\rho} \alpha \dot{\gamma} \delta \eta v$ (поривчасто) - $\dot{\rho} \alpha \delta \alpha \tilde{\imath} о \varsigma$ (поривчастий),

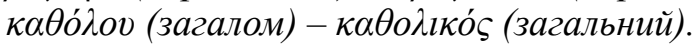

Відад'єктивна суфіксальна деривація не $\epsilon$ поширеним явищем у ДГ. 3 допомогою небага-

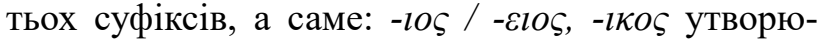
ються прикметники з певним відтінком значення,

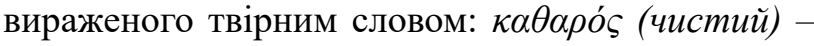

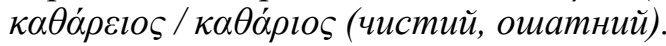

Префіксальний спосіб - це творення нового слова 3 допомогою префікса. У грецькій мові лінгвісти виділяють [19] два типи префіксів: невіддільні префікси та префікси, які мають автономну форму, але не мають чіткого лексичного значення (воно залежить від значення основи, 3 якою сполучається префікс). Типовими для прикметника невіддільними $\epsilon$ заперечні префікси $\dot{\alpha}-$ та $\delta v \sigma-:$

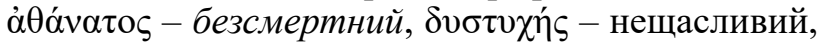
а також підсилювальні $\dot{\alpha}-, \dot{\alpha} \rho t-, \dot{\varepsilon} \rho t-, \zeta \alpha-, \delta \alpha-, \beta \rho t-:$

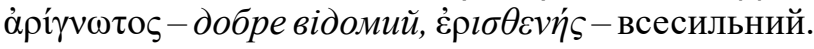


Серед перелічених префіксів - $\dot{\alpha}$ виконує декілька функцій: $\dot{\alpha}$-privativum (заперечення ознаки, відсутність): о̆voos - нерозумний, $\dot{\alpha}$-intensivum

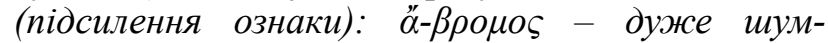
ний, $\dot{\alpha}$-copulativum (рівність, однаковість): $\dot{\alpha}-\tau \dot{\alpha} \lambda \alpha v \tau о \varsigma$ - вагою однаковий, $\dot{\alpha}$-protheticum (не

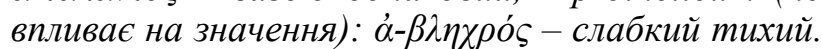
Префікси другого типу представлені значно ширшим рядом - це здебільшого давньогрецькі прийменники або прислівники, які у певних виразах зберігають свою функцію і вживаються окремо (наприклад, $\dot{\alpha} \mu \varphi \dot{\varphi} \varphi \alpha \lambda о \varsigma-з$ двома гребенями < $\dot{\alpha} \mu \varphi \grave{\imath}$

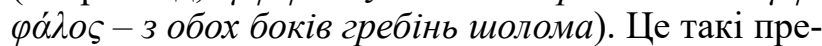
фікси: $\dot{\alpha} \mu \varphi l_{-}, \dot{\alpha} v \alpha-, \dot{\alpha} v \tau l-, \dot{\alpha} \pi o_{-}, \delta l \alpha-, \dot{\varepsilon} l \varsigma_{-}, \dot{\varepsilon} v-, \dot{\varepsilon} \kappa-, \dot{\varepsilon} \pi l-$, $\kappa \alpha \tau a-, \mu \varepsilon \tau \alpha-, \pi \alpha \rho \alpha-, \pi \varepsilon \rho l^{-}, \pi \rho o_{-}, \pi \rho \varsigma_{-},, \sigma v v_{-}, \quad \dot{v} \pi \varepsilon \rho-$,

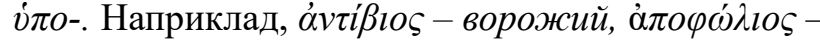

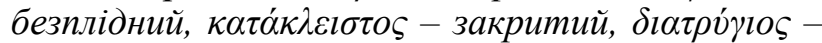

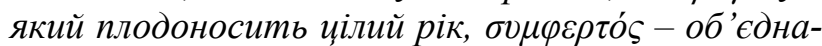

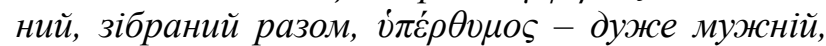
vंлохвірюо - який є під рукою.

Префікси приєднуються як до цілого твірного слова, не міняючи його частиномовного статусу й морфологічних ознак (у вітчизняній лінгвістиці таке явище називається чистою префіксацією), так і до основи слова із супровідною суфіксацією.

Чиста префіксація вважається близькою до словоскладання (або його різновидом), адже обидва способи мають однакові формальні та функційні особливості, значення слова в ролі другого компонента не зливається зі значенням префікса, крім того, деякі префікси генетично походять від

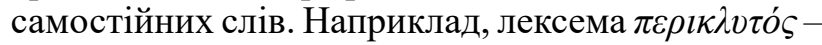
всюди славний складається із префікса $\pi \varepsilon \rho l$ - (походить від прислівника «довкола, всюди») та при-

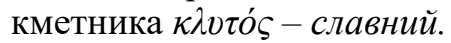

Префіксально-суфіксальним способом (конфіксацією) утворюються ад'єктиви від інших

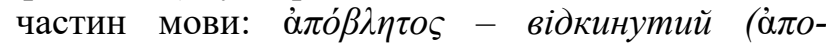
$+\beta \dot{\alpha} \lambda \lambda \omega-\kappa и д а т и+\tau о \varsigma), \quad \dot{\varepsilon} \rho \imath \rho \varepsilon \mu \varepsilon \dot{\varepsilon} \tau \eta \varsigma-я к и и ̆$

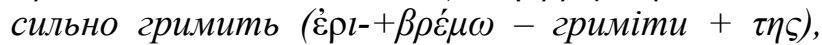

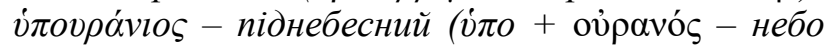
+ los). Отже, афіксом виступає двокомпонентний перерваний формант, «префіксальна і суфіксальна частини якого діють комплексно, формуючи своєрідну словотворчу рамку, в яку вкладається твірна основа» $[14$, с. 484]. Трапляються випадки приєднання префікса (та суфікса) до основи 3 попередньою префіксацією, відтак, у кінцевого деривата наявні два префікси: $\delta v \sigma-\alpha v \tau i \beta \lambda \varepsilon \pi \tau o \varsigma$ (якому

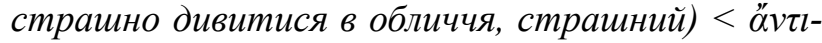

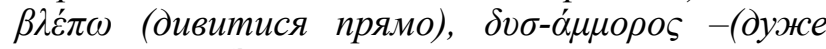

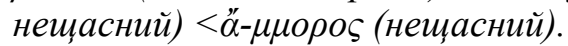

Творення ДГ прикметників із двома та більше твірними основами становить складання, один із найпродуктивніших способів словотворення у ДГ мові, що поділяється на: основоскладання / композицію та словоскладання / юкстапозицію (про поділ складних слів на би́v $\theta \varepsilon \tau \alpha$ (композити) та $\pi \alpha \rho \alpha ́ \theta \varepsilon \tau \alpha$ (юкстапозити) згадується ще в античних працях [16]). Твірною базою виступає не одна

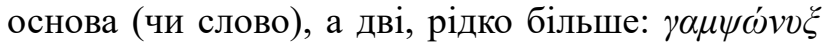
$(\gamma \alpha \mu \psi o ́ \varsigma$ o від того, є твірними основи чи слова, складні слова називають композитами і юкстапозитами $[14$, c. 413$]$.

Композити - це похідні складні слова, утворені способом складання двох основ або слова та основи

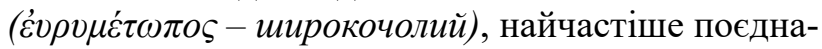
них інтерфіксом $o, \alpha / \eta, \imath,(\varphi \imath \lambda o ́ \xi \varepsilon \imath v o \varsigma-г о с т и н н и и ̆$,

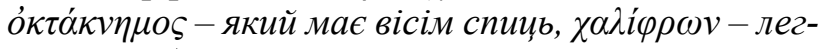
коважний).

Відношення між компонентами композитів можуть бути адитивними / кумулятивними

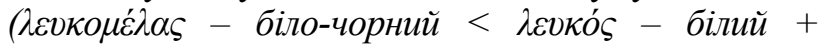

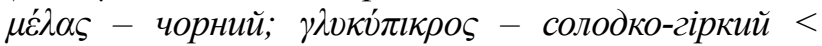

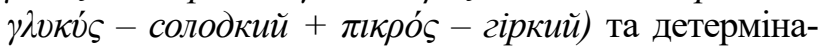

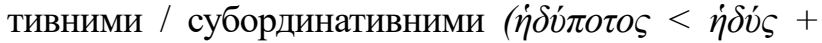
ті́v - приємний для пиття). Складних слів, утворених на базі адитивних відношень, серед ДГ композитів, прикметників зокрема, не багато (сучасна ж грецька мова характеризується великою кількістю так званих dvandva-композитів [20]). Більшість ДГ композитних прикметників $€$ детермінативними та побудовані на принципах підрядного зв'язку

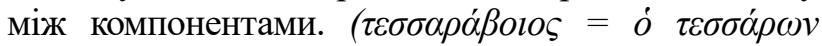

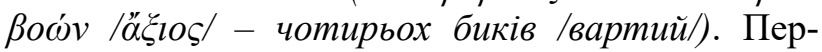
ший компонент виражається такими частинами мови, як прикметник (каковін

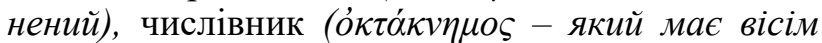

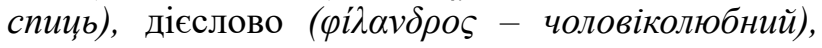

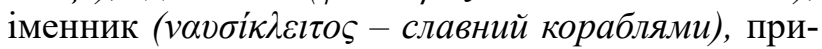

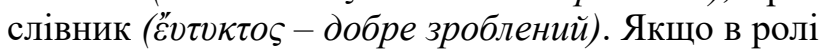
першого словотвірного компонента виступають іменники чи прикметники, то вони можуть бути представлені у формі цілого слова в називному відмінку однини, в давальному відмінку однини та множини, основи слова та навіть декількох видів основи (детальніше див. [5; 15]), наприклад:

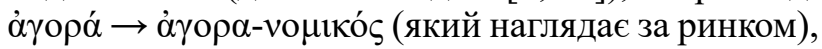

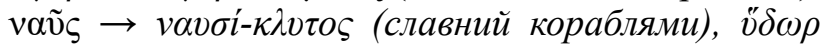

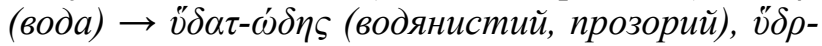

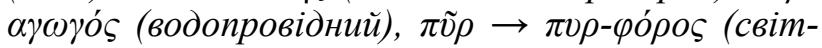

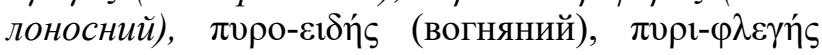
(палаючий вогнем). Невідмінювані частини мови, такі як прислівник чи кількісний числівник, у ролі першого компонента не змінюються, можуть зазнавати лише певних фонологічних змін [15]:

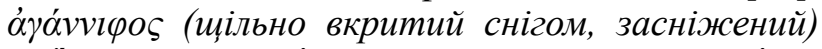

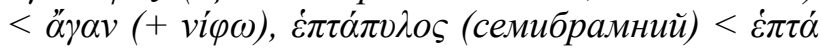
$(+\pi \dot{\lambda} \lambda \eta)$. ДГ композитні ад’єктиви відповідно утворюються за різними моделями 3 керівним словом в ролі першого чи другого компонента: числівник + іменник $(\mathrm{Num}+\mathrm{S}): \dot{\varepsilon} \xi \dot{\varepsilon} \tau \eta \varsigma-$ шестирічний < $\check{\xi} \xi \dot{\varepsilon} \tau \tilde{\omega} v ;$ прикметник + іменник $(\mathrm{A}+\mathrm{S})$ : 
$\chi \alpha \lambda \kappa \varepsilon \dot{\varphi} \omega v о \varsigma-$ мідноголосий < $\dot{o} / \check{\varepsilon} \chi \omega v / \chi \dot{\lambda} \lambda \kappa \varepsilon о \nu$ $\varphi \omega v \eta ́ v$, іменник + дієслово $(\mathrm{S}+\mathrm{V}): \kappa v \kappa \lambda о \tau \varepsilon \rho \eta \dot{~} \varsigma-$

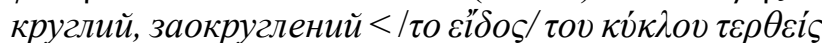
та ін. Іменник чи прикметник у ролі першого компонента 3'єднується 3 другим зазвичай інтерфіксом $o$, дієслово - інтерфіксами $\varepsilon, \sigma l, l, o$ [5]. Композиція у ДГ супроводжується суфіксацією, що надає слову морфологічного оформлення (в українській мові окремо виділяється суфіксально-складний спосіб словотворення [12, с. 32]): $\pi \alpha \nu-\delta \dot{\eta} \mu-l о \varsigma-в с е-$

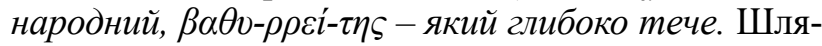
хом додаткової суфіксації композитів (тобто, на базі складної основи) можуть утворюватися нові,

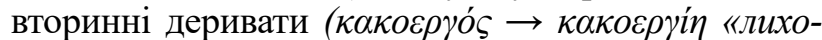
дійний-лиходійність»).

Щодо семантичних ознак («семантичної центричності» [18, с. 295]), детермінативні компо-

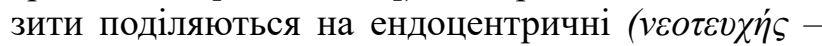
недавно зроблений, новий), лексико-граматичні та синтаксичні, властивості яких відповідають головним їхнім елементам [8], та екзоцентричні (відомі в лінгвістиці як багувриги (санскр. bahuvrihi), у яких значення композита не виводиться із суми значень його компонентів і набуває іншого семантичного відтінку. Значення ендоцентричних композитів, отже, акумулює значення його компонентів, це може бути означуване й означення, суб'єкт

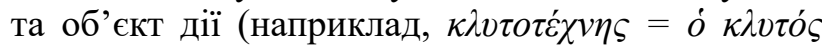
$\left.\tau \alpha \tilde{l} \varsigma \tau \varepsilon^{\prime} \chi v \alpha u \varsigma ; \varphi v \gamma o \pi \tau o ́ \lambda \varepsilon \mu o \varsigma=\dot{o} \varphi v \gamma \tilde{\omega} v \tau o v \pi \delta ́ \lambda \varepsilon \mu o v\right)$. Багувриги за формою $є$ детермінативними складними словами, які виражають володіння якоюсь ознакою. Їхнє значення не встановлюється шляхом трансформації складного слова у сполучення

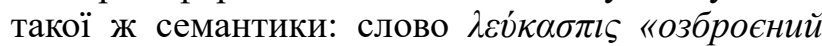

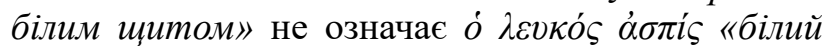
щит» (виходячи зі структури слова), а наближається своїм значенням до групи слів $\delta$ ह́ $\chi \omega v \lambda \varepsilon v \kappa o ̀ v$ $\dot{\alpha} \sigma \pi i \delta \alpha$ «який має білий щит». Або ж структура композита оiохiтюv (одягнений лише в хітон) структурно виводиться зі словосполучення $(\dot{o}$ oĩos $\chi l \tau \dot{v}$ - один хітон), однак, семантично моти-

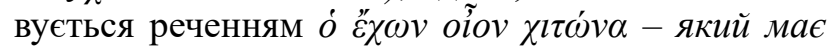
один хітон (дієслово виражається імпліцитно). Мабуть тому деякі лінгвісти [2] вважають, що більша частина складних слів - це трансформація речення, яка відбувається у процесі двох етапів: згортання речення у словосполучення, а словосполучення - у складне слово.

Юкстапозити - похідні складні слова, які утворюються шляхом складання цілих слів (зрощенням). Це лексикалізація синтаксичної оди-

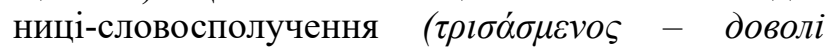
охочий < $\left.\tau i^{\prime} \varsigma \dot{\alpha} \sigma \mu \varepsilon v o \varsigma\right)$. Такі слова «у всіх формах повністю тотожні за морфемним складом еквівалентному словосполученню. Зберігається також синтаксичний зв'язок компонентів і їхню послідовність» $[14$, с. 194]. Зрощення не є про- дуктивним способом творення давньогрецьких прикметників. Найчастіше лексикалізуються словосполучення з першим адвербіальним компонен-

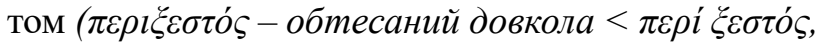

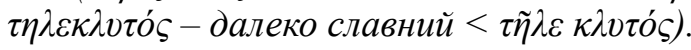

Основною спільною ознакою складного слова та словосполучення є семантична єдність. Словосполучення, як і складне слово, за словами Г.М. Удовиченка, виражає єдину, хоч і в лексично членній формі, назву предмета, поняття чи уявлення [13, с. 11]. Основною диференційною ознакою між твірним словосполученням і складним словом $\epsilon$ ціліснооформленість останнього, яка стосується структурної єдності, а в ДГ - це ще й сталий порядок розташування компонентів $\mathrm{i}$ неможливість його змінити.

Ще одним аспектом розгляду грецьких прикметників із погляду словотвору $\epsilon$ з'ясування дериваційних можливостей самих похідних ад'єктивів як ціліснооформлених одиниць, зокрема у процесах утворення вторинних дериватів. Такий аналіз, на нашу думку, допомагає виявити єдність форми та змісту, а також функційні потенції похідних одиниць у мовній системі. Отже, дериваційний потенціал (за О.А. Земською, «дериваційні валентності» [6, с. 75]) похідних прикметників як твірних баз різний, залежить від кожної лексеми зокрема чи певного типу лексем. На це впливає низка факторів: лексико-граматичні особливості конкретної одиниці, семантична наповненість слова, історичний етап розвитку досліджуваної мови. Слід зазначити, що основи різних груп ад'єктивів по-різному використовуються у словотворенні (наприклад, основи якісних прикметників стають базою для різних лексико-граматичних розрядів слів, а основи відносних прикметників не утворюють деяких частин мови взагалі). На дериваційні можливості впливає також специфіка сполучуваності конкретного слова, яка відображає обсяг означуваних ним денотатів [4, с. 25]. Наприклад, похідна лексема $\dot{\alpha} \varphi \rho \alpha \delta \dot{\eta} \varsigma$ зі значенням «нерозважливий, нерозумний», характеризується широкими дериваційними можливостями

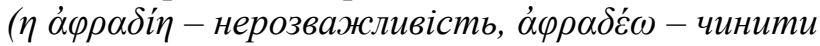
нерозважливо, $\dot{\alpha} \varphi \rho \alpha \delta \dot{\varepsilon} \omega \varsigma$ - нерозважливо). Отже, твірні лексичні одиниці та їхні деривати утворюють або словотвірні пари (що становить твірне слово та безпосередньо пов'язане

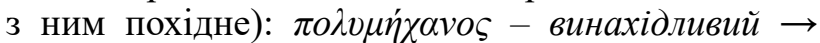

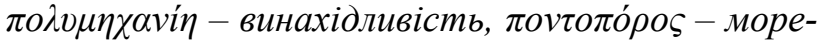

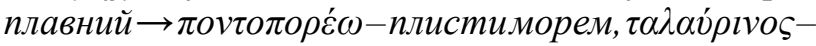

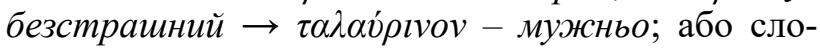
вотвірні парадигми (сукупність похідних різних частиномовних зон, що мають спільну твірну базу й розташовані на одному ступені похід-

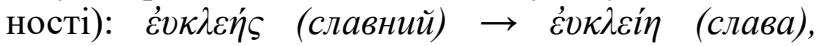
$\dot{\varepsilon} v \kappa \lambda \varepsilon i \tilde{\omega} \varsigma$ (славно); $\chi \alpha \lambda i \varphi \rho \omega \nu$ (легковажсний) $\rightarrow$ 


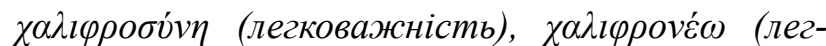

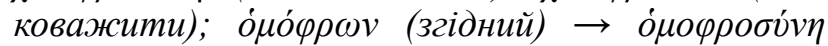

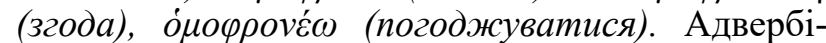
альна частиномовна зона відад'єктивних дериватів подекуди характеризується кількома паралель-

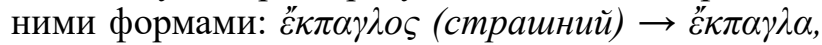

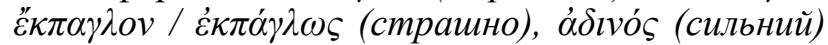
$\rightarrow \dot{\alpha} \delta \imath v \alpha \dot{\alpha}, \dot{\alpha} \delta \imath v o ́ v$ / $\dot{\alpha} \delta \imath \tilde{\omega} \varsigma$ (сильно), $\dot{\alpha} \sigma \varphi \alpha \lambda \dot{\eta} \varsigma$ (стійкий, міцинй, непохитний) $\rightarrow \dot{\alpha} \sigma \varphi \alpha \lambda \bar{\varepsilon} \varsigma / \dot{\alpha} \sigma \varphi \alpha \lambda \dot{\varepsilon} \omega \varsigma$ (твердо, непохитно, надійно).

Похідні прикметники, від яких утворилися вторинні деривати, є твірними, адже вони (хоч не завжди повністю) входять у структуру дериватів (твірна основа $є$ складною, про що вже згадувалося в роботі). Утворені від композитів деривати, як видно з прикладів, здебільшого не змінюють вихідного значення твірної бази.

Підсумовуючи аналіз словотворення ДГ ад'єктивів, підкреслимо основне. Внаслідок словотвірних процесів (афіксації та складання) утворюються похідні (прості та складні за структурою) лексеми. Найбільшою різноманітністю суфіксів характеризуються ДГ відсубстантивні прикметники. Більшість ДГ префіксів $є$ початково прийменниками чи прислівниками. ДГ префіксальні ад'єктиви в багатьох випадках походять від інших частин мови, тому супроводжуються суфіксацією. Афіксальні дериваційні процеси в ДГ (як і в інших мовах) залежать як від твірної основи (належності до частини мови, структурної будови) так і від афікса (сполучуваності, продуктивності та конкретних вимог щодо основи). Основними ознаками ДГ складних ад'єктивів є ціліснооформленість i семантична монолітність. Ад'єктиви, утворені шляхом основоскладання, здебільшого побудовані на основі детермінативного типу зв'язку між компонентами. Особливою чисельністю виділяються ДГ екзоцентричні композити, характерна ознака яких - наявність експліцитно невиражених компо-

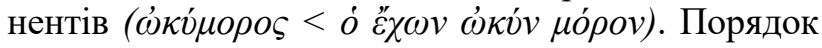
розташування компонентів вихідних і похідних одиниць переважно збігається, однак трапляється

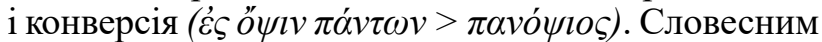
оформленням більшості композитів $є$ інтерфікси та кінцеві форманти. Словоскладання $є$ найменш продуктивним способом творення ДГ прикметників. Юкстапозити в системі ДГ ад'єктива - це здебільшого лексикалізовані словосполучення 3 першим адвербіальним компонентом Структура ДГ похідних прикметників (чи це одиниці 3 однією твірною основою, чи з двома) не впливає на здатність до утворення відад'єктивних вторинних дериватів. Семантика вторинних дериватів базується переважно на основних значеннях твірного прикметника.

Здійснене дослідження відкриває перспективи для подальшого аналізу ад'єктивів на матеріалі різних мов, включаючи зіставний аспект, а також особливостей словотвірних процесів у різних мовних системах.

\section{ЛІТЕРАТУРА}

1. Аристотель. Сочинения : в 4 т. Москва : Мысль, 1978. Т. 2. 688 с.

2. Бенвенист Э. Общая лингвистика. Москва : Прогресс, 1974. 447 с.

3. Грищенко А.П. Прикметник в українській мові. Київ : Наук. думка, 1978. 20 с.

4. Грещук В.В. Український відприкметниковий словотвір. Івано-Франківськ : Вид-во «Плай», 1995. $208 \mathrm{c}$.

5. Звонська Л.Л. Давньогрецька мова. Київ : ВПЦ «Київський національний університет», 2011. URL: https://shron1.chtyvo.org.ua/Zvonska_Lesia/Davnohretska_mova.pdf.

6. Земская Е.А. О парадигматических отношениях в словообразовании. Москва : Наука, 1978. С. 63-77.

7. Клименко Н.Ф. Словотвірна морфеміка сучасної української літературної мови. НАН України ; Ін-т мовознавства ім. О.О. Потебні. Київ, 1998. 162 с.

8. Клименко Н.Ф. Словотворча структура і семантика складних слів у сучасній українській мові. Київ : Наук. думка, 1984. 252 с.

9. Кубрякова Е.С. Части речи в ономасиологическом освещении. Москва : Наука, 1978.114 с.

10. Ковалик I.I. Питання іменникового словотвору в східнослов'янських мовах у порівнянні з іншими слов’янськими мовами. Ч. І. Львів : Вид-во ЛДУ, 1958. 154 с.

11. Плющ М.Я. Граматика української мови. Морфеміка. Словотвір. Морфологія : підручник. Київ : Видавн. Дім «Слово», 2010. 328 с.

12. Словотвір сучасної української літературної мови. Київ : Наук. думка, 1979. 406 с.

13. Удовиченко Г.М. Словосполучення в сучасній українській літературній мові. Київ : Наук. думка, 1968. $228 \mathrm{c}$.

14. Українська мова. Енциклопедія / редкол. : В.М. Русанівський, О.О. Тараненко, М.П. Зяблик та ін. ; НАН України ; Ін-т мовознавства ім. О.О. Потебні ; Ін-т української мови. Київ : Вид-во «Українська енциклопедія» ім. М.П. Бажана, 2000. 750 с.

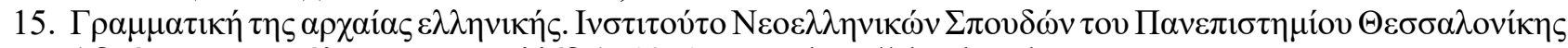

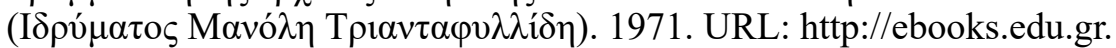

16. Hoenigswald H.M. Pan-Compounds in Early Greek. Language. 1940. Vol. 16. № 3. P. $183-188$. 
17. Manolessou Io., Ralli A. From Ancient Greek to Modern Greek. Word-Formation. An International Handbook of the Languages of Europe. De Gruyter. 2015. URL: https://www.angelaralli.gr.

18. Meissner T., Tribulato O. Nominal Composition in Mycenaean Greek. Transactions of the Philological Society. 2002. Vol. 100. № 3. P. 289-330.

19. Ralli A. Greek word formation. Morphology (Languages and Linguistics): De Gruyter. 2013. URL: https://www.academia.edu/168288/Greek_word_Formation

20. Ralli A. Modern Greek dvandva V+V compounds: A linguistic innovation in the history of the IndoEuropean languages. Word Structure 2. 2009. P. 48-68.

21. Дворецкий И.Х. Древнегреческо-русский словар. Москва: Государственное издательство иностранных и национальных словарей. 1958. Т. 1 : 1028; Т. 2 : 1905.

22. Chantraine P. Dictionnaire étymologique de la langue Greque. Histoire de mots. Paris : Éditions Klincksieck, 1968. Vol. I. 305 p. ; 1970. Vol. II. 607 p. ; 1974. Vol. III. 962 p. ; 1977. Vol. IV-1. 1164 p. ; 1980. Vol. IV-2. 1305 p.

\section{REFERENCES}

1. Aristotel (1978) Sochinenia: v 4 t. [Works: in 4 volumes]. Moskva : Mysl. T. 2. 688 pp (In Russ.).

2. Benvenist E. (1974). Obshchaya linguistika [General linguistics]. Moskva : Progress. 447 p. (In Russ.).

3. Gryshchenko A.P. (1978) Prykmetnyk v ukrainskiy movi [Adjective in Ukrainian language]. Kyiv : Naukova dumka. 20 p. (In Ukr.).

4. Greshchuk V.V. (1995) Ukrainskyi vidprykmetnykovy slovotvir [Ukrainian deadjectival word-formation]. Ivano-Frankivsk : Vyd-vo "Plaj”. 208 p. (In Ukr.).

5. Zvonska L.L (2011) Davnjohretska mova [The Ancient Greek]. Kyiv: VPC "Kyivskyi natsionalny universytet". URL: https://shron1.chtyvo.org.ua/Zvonska_Lesia/Davnohretska_mova.pdf.

6. Zemskaja E.A (1978) O paradigmaticheskikh otnoshenijakh v slovoobrazovanii [About paradigmatic relations in word-formation]. Moskva : Nauka. P. 63-77 (In Russ.).

7. Klymenko N.F. (1998) Slovotvirna morphemika suchasnoi ukrainskoi literaturnoi movy [Word-forming morphemics in modern Ukrainian literary language]. NAN Ukrainy; In-t movoznavstva im. O.O. Potebni. Kyiv. 162 p. (In Ukr.).

8. Klymenko N.F. (1984) Slovotvorcha struktura i semantyka skladnych sliv [Word-forming structure and semantics of the compound words]. Kyiv : Naukova dumka. 252 p. (In Ukr.).

9. Kubryakova E.S. (1978) Chasti rechi v onomasiologicheskom osveshchenii [Parts of language in the light of onomasiology]. Moskva: Nauka. 114 p. (In Russ.).

10. Kovalyk I.I (1958) Pytannja imennykovoho slovotvoru v skhidnoslovjanskykh movakh u porivnjanni z inshymy slovjanskymy movamy [The question of nominal word-formation in East Slavic languages in compare with other Slavic languages]. The question of nominal word-formation in East Slavic languages in compare with other Slavic languages. P.I. Lviv : Vyd-vo LDU., 154 p. (In Ukr.).

11. Pljushch M.Ja. (2010) Gramatyka ukrajinskoji movy. Morfemica. Slovotvir: pidruchnyk [The grammar of Ukrainain language. Morphemics. Word-formation: textbook]. Kyiv : Vydav.dim "Slovo". 328 p. (In Ukr.).

12. Slovotvir suchasnoi ukrainskoi literaturnoi movy (1979) [Word-formation of modern Ukrainian literary language]. Kyiv: Naukova dumka. 406 p. (In Ukr.).

13. Udovychenko G.M. (1968) Slovospoluchennja v suchasnij ukrainskij literaturnij movi [Word-phrases in modern Ukrainian literary language]. Kyiv: Naukova dumka. 228 p. (In Ukr.).

14. Ukrainska mova. Encyklopedia. (2000) [Ukrainian language. Encyclopedia]. Kyiv : Vyd-vo "Ukrainska encyklopedia" im. M.P. Bazhana. 750 p. (In Ukr.).

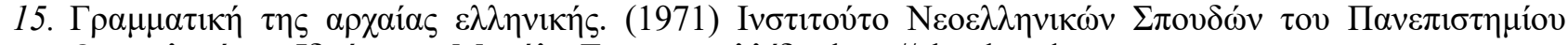

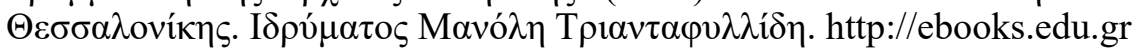

16. Hoenigswald H.M. (1940) Pan-Compounds in Early Greek. Language. Vol.16. № 3. P. 183-188.

17. Manolessou Io., Ralli A. (2015) From Ancient Greek to Modern Greek. Word-Formation. An International Handbook of the Languages of Europe. De Gruyter. URL: https://www.angelaralli.gr.

18. Meissner T., Tribulato. O. (2002) Nominal Composition in Mycenaean Greek. Transactions of the Philological Society. Vol. 100. № 3. P. 289-330.

19. Ralli A. Greek word formation. (2013) Morphology. Languages and Linguistics. De Gruyter. URL: https://www.academia.edu/3168288/Greek_word_Formation.

20. Ralli A. (2009) Modern Greek dvandva V+V compounds: A linguistic innovation in the history of the Indo-European languages. Word Structure 2. P. 48-68.

21. Dvoretskiy I.Kh. (1958) Drevnegrechesko-russkij slovar [Ancient Greek-Russian vocabulary]. Moskva: Gosudarstvennoje izdatelstvo inostrannykh i nacyonalnykh slovarej словарей. V. 1: 1028 p. V. 2:1905 p.

22. Chantraine P. (1968) Dictionnaire étymologique de la langue Greque. Histoire de mots. Paris : Éditions Klincksieck. Vol. I. 305 p. ; 1970. Vol. II. 607 p. ; 1974. Vol. III. 962 p. ; 1977. Vol. IV-1. 1164 p. ; 1980. Vol. IV-2. 1305 p. 